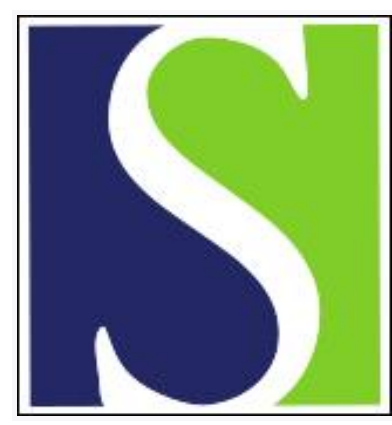

Scand J Work Environ Health 1990;16(2):96-101

https://doi.org/10.5271/sjweh.1803

Issue date: 01 Apr 1990

Reduction of births in Italy after the Chernobyl accident.

by Bertollini R, Di Lallo D, Mastroiacovo P, Perucci CA

Affiliation: Epidemiology Unit, Lazio Region, Rome, Italy. 


\title{
Reduction of births in Italy after the Chernobyl accident
}

\author{
by Roberto Bertollini, MD, MPH, ${ }^{1}$ Domenico Di Lallo, MD, ${ }^{1}$ Pierpaolo Mastroiacovo, MD, ${ }^{2}$ \\ Carlo A Perucci, MD ${ }^{1}$
}

\begin{abstract}
BERTOLLINI R, DI LALLO D, MASTROIACOVO P, PERUCCI CA. Reduction of births in Italy after the Chernobyl accident. Scand J Work Environ Health 1990;16:96-101. After the Chernobyl accident serious concern spread throughout Italy about the possible effects of the consequent exposure to radioactivity on fetuses. A reduction of births in the first three months of 1987 , and particularly in February (7.2\% reduction in the birth rate), was observed throughout Italy. In April-June 1987 a $4.8 \%$ increase in the number of births was observed. The magnitude of both phenomena varied in different areas of the country. The total number of births in the first six months of 1987 was very similar to the expected (264 241 versus 263659 ). Induced abortions increased in Lombardia (northern Italy) in June $(+1.6 \%)$ and July of $1986(+3.4 \%)$ and in Campania (southern Italy) in June $(+12.7 \%)$ and August $(+4.3 \%)$. No increase in legal abortions was detected in Lazio (central Italy). Italian data suggest a voluntary decrease in the number of planned pregnancies and the termination of some of them in the first weeks after the accident as a consequence of postdisaster stress.
\end{abstract}

Key terms: birth rate, induced abortion, radiation effects.

After the Chernobyl accident the radioactive cloud produced by the explosion of the Soviet nuclear plant spread over Europe and virtually the whole northern hemisphere from the end of April to the beginning of May 1986.

The cloud reached Italy on April 30th. An increase in environmental radioactivity was detected throughout the country, the highest observed levels occurring in northern Italy. The Italian government introduced countermeasures to limit exposure to radiation; these measures included a prohibition of the marketing and consumption of fresh milk, milk products, and leafy vegetables. The ban was introduced on the third of May and lasted until May 12th for leafy vegetables, and until May 24th for milk and milk products.

The additional radioactivity was low throughout the country. Estimates of the radioactive exposure of individuals in the following months showed that the average effective dose of adults in Italy in the first year after the accident was $0.6 \mathrm{mSv}(60 \mathrm{mRem})$; exposure was higher in the north $(0.7 \mathrm{mSv}=70 \mathrm{mRem})$ than in central $(0.6 \mathrm{mSv}=60 \mathrm{mRem})$ and in southern $(0.5 \mathrm{mSv}=50 \mathrm{mRem})$ Italy (1). In comparison, the average natural background radiation is about $2 \mathrm{mSv} /$ year $(200 \mathrm{mRem})(1)$. Therefore the additional exposure due to the accident was between 25 and $35 \%$ of the yearly dose of the natural background.

The consequences of the accident on the environment and on health were extensively covered by the media. In figure 1 the number of articles about the ex-

\footnotetext{
I Epidemiology Unit, Lazio Region, Rome, Italy.

2 Catholic University, Paediatric Department, Rome, Italy.
}

Reprint requests to: Dr R Bertollini, Epidemiology Unit, Lazio Region, Via di S Costanza, 53, 1-00198 Rome, Italy. plosion and its effects on health in the three major national Italian newspapers (La Repubblica, Corriere della Sera, La Stampa) is shown by week after the explosion. Several articles dealt with the risk of cancer and with that of fetal abnormalities. For instance, titles such as "Fetal Abnormalities after Chernobyl" and "Anxiety of Future Mother" appeared in Corriere della Sera on May 9th and May 21th, respectively.

Conflicting information and false rumors spread considerable alarm among the public in general and among pregnant women in particular. The International Atomic Energy Agency predicted an increase in the number of induced abortions in Western Europe as a result of the fear of adverse fetal outcomes in pregnancies of women exposed to the radiation following Chernobyl (2). A reduction in the number of births in the cohort of conceptions taking place around the time of the accident has been reported for Greece and Sweden $(3,4)$.

We studied figures on induced abortions and births regarding embryos at early gestational ages during the period of acute radioactive contamination (May 1986) and in the immediately following months. The aim of the study was to evaluate whether the number of births and that of induced abortions changed in the months following the Chernobyl accident as a consequence of postdisaster stress (5).

\section{Subjects and methods}

\section{Births}

Babies conceived in May 1986 could be expected to be born in the last weeks of January and in February 1987. Data on births from January to June 1987 were analyzed for the entire country and the three main 
geographic areas (northern, central and southern Italy) (6). A separate analysis was performed for each month and geographic area. In order that the expected births in 1987 could be calculated, data by month from 1977 to 1986 were studied for time trends (figure 2).

The data showed a consistent decrease in the number of births over the 10 years studied with a change in the slope of the curve (particularly for January, February, and March), which occurred in 1980-1981. Linear regression models, with and without data transformations, were applied to each data set, either for the entire time period or for the last five or six years of observation. The model which best fit the data was chosen for the prediction of expected births in 1987 . The statistics $R$ square was used to measure the goodness-of-fit of the model. Similar time trends were observed for the country as a whole and for the three geographic areas studied.

The standard error of the 1987 prediction was used to calculate the $95 \%$ confidence intervals of the expected numbers of births. Statistical testing of the difference between the observed and expected num- bers of births was performed with the use of the $t$ distribution with n-2 degrees of freedom where " $n$ " was the number of years in each regression model (7).

\section{Induced abortions}

Monthly data on induced abortion were available to us for the following three large regions: Lombardia (in the north), Lazio (in the central part of the country), and Campania (in the south). These three regions were representative of the main geographic areas of the country. For the analysis of induced abortions, pregnancies at risk were defined as follows: pregnancies begun in May 1986 and those not past the 10th week of gestation on 1 May 1986. Italian law allows for legal abortion within the first 12 weeks without special restrictions except that $7 \mathrm{~d}$ must pass between the request for the abortion and the actual operation. In many medical services providing abortions, there is a long waiting list for these operations.

Because it was impossible to select the exposed cohort of conceptions according to the date of the last
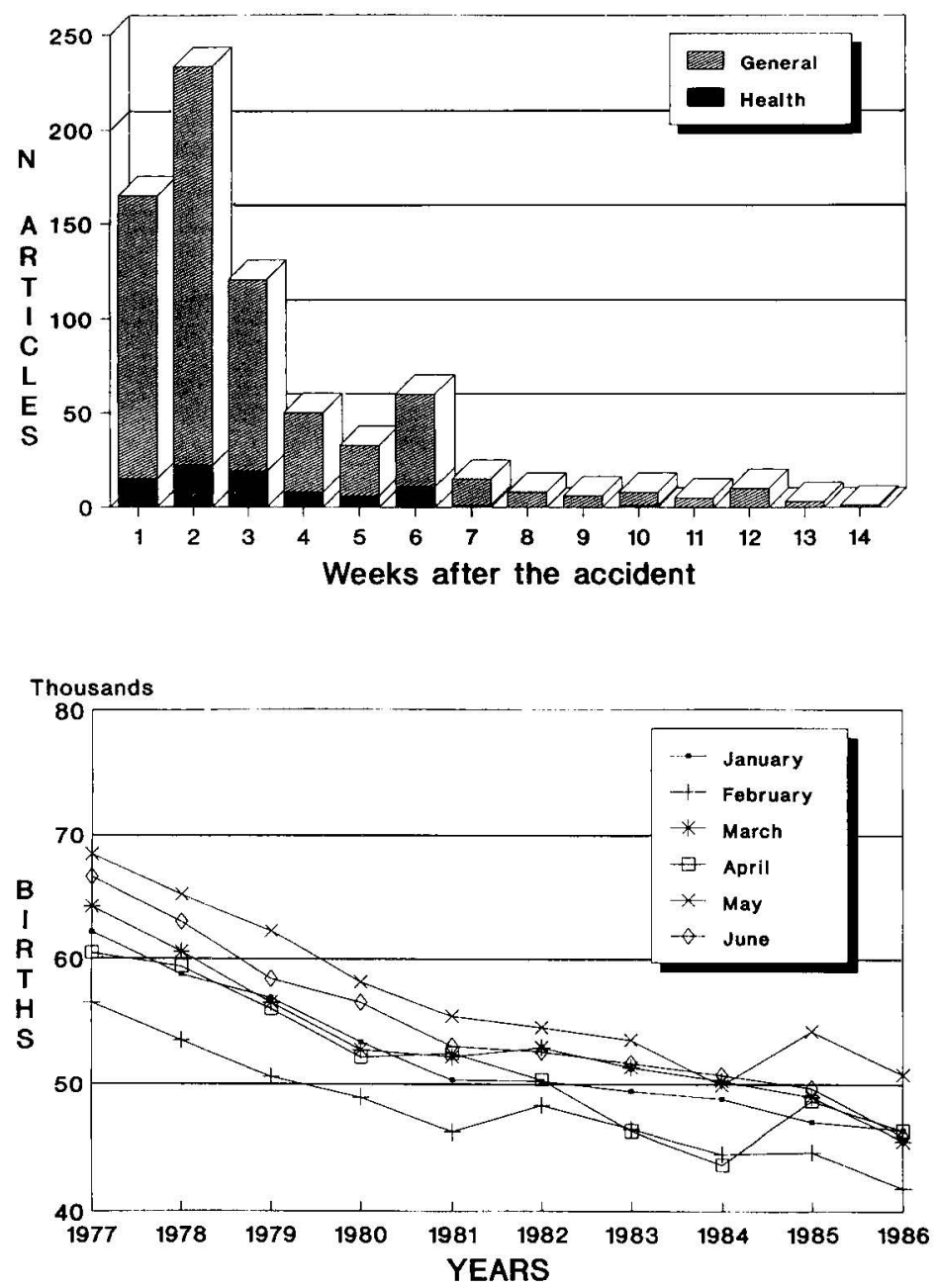

Figure 1. Number of articles about the Chernobyl accident in three national Italian newspapers by subject and by week after the accident.
Figure 2. Number of births by year for $1977-1986$ and by month of birth (January-June) in (taly. 
menstrual period (this information not being available at the time) and because of the delay between the request for an induced abortion and the actual operation, the time period to be examined included the second half of May and all of June and July.

The abortion rates for 100 known pregnancies were obtained by dividing the number of induced abortions occurring in a given month by the sum of the births occurring six months later and the induced abortions. This approach, suggested by Tietze (8), allowed for a better evaluation of the frequency of induced abortions among the defined cohorts of pregnancies continuing to termination (ie, with the exclusion of spontaneous abortions and fetal deaths) when the date of the last menstrual period was unknown, ie, with the assumption that most of the induced abortions took place in the third month of pregnancy. The registered frequency of induced abortions in Italy sharply increased after legalization (1978) and reached a plateau in 1982. In figure 3 the abortion rates for 1982-1985 are shown for the entire country, and for the three studied regions as well (9).

Since no clear-cut time trend was observed, the expected abortion rates were obtained by summing the figures for births and induced abortions in the 19821985 time period for each region and each month. Statistical testing of the difference between the observed and expected rates was carried out using the approximation of the binomial proportion to the normal distribution (10). The $95 \%$ confidence intervals were obtained with the use of the quadratic equation suggested by Fleiss (11).

\section{Results}

In table 1 data on the observed and expected numbers of births in the time period January-June 1987 are summarized for the country as a whole and for the three main geographic areas. A cecline in the number of births was observed in January-March 1987, the decrease being the most marked in February. In Febru- ary the birth reduction was statistically significant at the $5 \%$ level for Lombardia and Lazio but not for Campania. Overall, in February, the birth rate declined by $7.2 \%$ (ie, by 2934 births), the decrease being $11.2 \%$ for Lombardia, $5.3 \%$ for Lazio, and $4.8 \%$ for Campania. When the figures for the first three months of 1987 were added, 125517 births were observed versus 131309 expected (for a difference of 5792 births). In the period April-June 1987 the number of births increased (by 6374 births). The increase was marked in Lombardia and Lazio and was statistically significant for Lazio in June. Overall in the first six months of 1987 the number of expected and observed births was nearly identical (263 659 expected versus 264241 observed).

In table 2 the abortion rates are compared by month and by region for May-August 1986. An increase was observed in June $(\mathrm{P}=\mathrm{NS})$ and July $(\mathrm{P}<0.05)$ in Lombardia, and in June $(\mathrm{P}<0.0001)$ and August $(\mathrm{P}=\mathrm{NS})$ in Campania. In the other months the abortion rates were lower than expected. In six out of eight months the decrease was statistically significant.

\section{Discussion}

The Chernobyl accident was a major environmental disaster whose medical and psychological consequences involved most European countries. The radiation fallout was unevenly distributed in Europe, but the radiation doses were in general relatively low (12). The long-term effects of low exposure to radiation on the general population are still controversial (13). Experimental investigations have shown that ionizing radiation can lead to miscarriages, congenital malformations, and growth and mental retardation (14). However there is no observational evidence of adverse fetal outcomes in humans due to exposure during pregnancy to levels of radioactivity such as those observed in Italy after the Chernobyl accident (15-17).

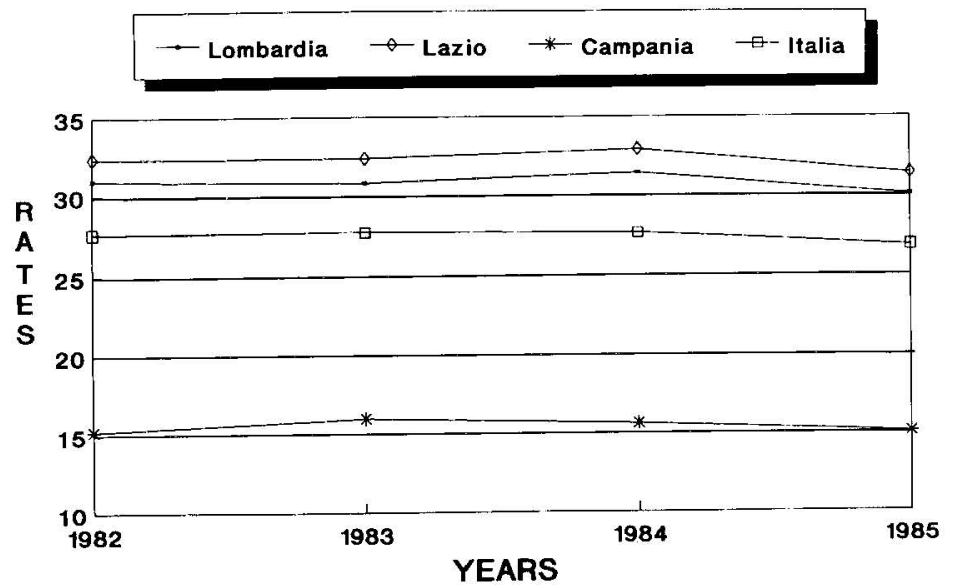

Figure 3. Induced abortion rates by 100 known pregnancies for Italy (Italia) and three selected regions in 1982-1985. (Lombardia $=$ northern Italy, Lazio $=$ central Italy, Campania = southern (taly) 
Valid estimates of exposure were available only several weeks after the accident. Uncertainties about the duration and intensity of the exposure in the first days and weeks spread alarm and panic throughout the population. In addition the manner in which the event was covered by the media, including inconsistencies in reporting the radioactivity measurements, did not help to clarify the extent of the risk and often increased public alarm. Anxiety and fear are difficult to measure, but, as far as reproduction is concerned, they

Table 1. Observed $(\mathrm{O})$ and expected $(\mathrm{E})$ numbers of births in Italy in 1987 by geographic area and by month of birth. $(95 \% \mathrm{Cl}=95 \%$ confidence interval)

\begin{tabular}{|c|c|c|c|c|c|c|c|c|}
\hline \multirow{3}{*}{ Region } & \multirow{3}{*}{$\begin{array}{l}\text { Time period } \\
\text { in the regres- } \\
\text { sion model }\end{array}$} & \multirow{3}{*}{$R^{2}$} & \multicolumn{4}{|c|}{ Births } & \multicolumn{2}{|r|}{ O-E } \\
\hline & & & \multirow[b]{2}{*}{0} & \multicolumn{3}{|c|}{ Predicted (E) } & \multirow{2}{*}{$\begin{array}{c}\text { Deviation } \\
(\%)\end{array}$} & \multirow{2}{*}{$\begin{array}{l}\text { 2-tailed } \\
\text { P-value }\end{array}$} \\
\hline & & & & $N$ & $\begin{array}{c}\text { Standard } \\
\text { error }\end{array}$ & $95 \% \mathrm{Cl}$ & & \\
\hline \multicolumn{9}{|l|}{ Italy } \\
\hline $\begin{array}{l}\text { January } \\
\text { February } \\
\text { March } \\
\text { April } \\
\text { May } \\
\text { June }\end{array}$ & $\begin{array}{l}1982-1986 \\
1982-1986 \\
1981-1986 \\
1977-1986 \\
1977-1986 \\
1977-1986\end{array}$ & $\begin{array}{l}0.97 \\
0.93 \\
0.85 \\
0.84 \\
0.86 \\
0.93\end{array}$ & $\begin{array}{l}43905 \\
37712 \\
43900 \\
43068 \\
47817 \\
47839\end{array}$ & $\begin{array}{l}45178 \\
40646 \\
45485 \\
41997 \\
46751 \\
43602\end{array}$ & $\begin{array}{r}505.2 \\
1049.3 \\
1601.4 \\
2888.7 \\
2987.9 \\
2211.3\end{array}$ & $\begin{array}{l}43570-46785 \\
37307-43985 \\
41040-49931 \\
36496-47498 \\
41061-52441 \\
39391-47813\end{array}$ & $\begin{array}{r}-2.82 \\
-7.22 \\
-3.49 \\
2.55 \\
2.28 \\
9.72\end{array}$ & $\begin{array}{c}0.05<P<0.10 \\
0.05<P<0.10 \\
\text { NS } \\
\text { NS } \\
\text { NS } \\
0.05<P<0.10\end{array}$ \\
\hline \multicolumn{9}{|c|}{$\begin{array}{l}\text { Lombardia } \\
\text { (northern Italy) }\end{array}$} \\
\hline $\begin{array}{l}\text { January } \\
\text { February } \\
\text { March } \\
\text { April } \\
\text { May } \\
\text { June }\end{array}$ & $\begin{array}{l}1982-1986 \\
1982-1986 \\
1981-1986 \\
1977-1986 \\
1977-1986 \\
1977-1986\end{array}$ & $\begin{array}{l}0.63 \\
0.96 \\
0.99 \\
0.89 \\
0.84 \\
0.85\end{array}$ & $\begin{array}{l}15530 \\
13106 \\
14798 \\
14483 \\
17176 \\
16777\end{array}$ & $\begin{array}{l}16922 \\
14754 \\
15547 \\
14110 \\
15908 \\
14623\end{array}$ & $\begin{array}{r}467.7 \\
232.2 \\
185.9 \\
1151.5 \\
1530.5 \\
1474.3\end{array}$ & $\begin{array}{l}15434-18410 \\
14015-15493 \\
15031-16063 \\
11917-16303 \\
12994-18822 \\
11816-17430\end{array}$ & $\begin{array}{r}-8.23 \\
-11.17 \\
-4.82 \\
2.64 \\
7.97 \\
14.73\end{array}$ & $\begin{aligned} 0.05 & <P<0.10 \\
0.005 & <P<0.01 \\
0.01 & <P<0.5 \\
& \text { NS } \\
& \text { NS } \\
& \text { NS }\end{aligned}$ \\
\hline \multicolumn{9}{|c|}{$\begin{array}{l}\text { Lazio } \\
\text { (central Italy) }\end{array}$} \\
\hline $\begin{array}{l}\text { January } \\
\text { February } \\
\text { March } \\
\text { April } \\
\text { May } \\
\text { June }\end{array}$ & $\begin{array}{l}1982-1986 \\
1982-1986 \\
1981-1986 \\
1977-1986 \\
1977-1986 \\
1977-1986\end{array}$ & $\begin{array}{l}0.63 \\
0.99 \\
0.92 \\
0.91 \\
0.90 \\
0.95\end{array}$ & $\begin{array}{l}7406 \\
6300 \\
7094 \\
7008 \\
8066 \\
8064\end{array}$ & $\begin{array}{l}7201 \\
6655 \\
7512 \\
6716 \\
7601 \\
6983\end{array}$ & $\begin{array}{r}482.9 \\
74.2 \\
201.5 \\
446.0 \\
516.9 \\
392.5\end{array}$ & $\begin{array}{l}5664-8738 \\
6419-6891 \\
6952-8071 \\
5867-7565 \\
6617-8585 \\
6236-7730\end{array}$ & $\begin{array}{r}2.85 \\
-5.33 \\
-5.56 \\
4.35 \\
6.12 \\
15.48\end{array}$ & $\begin{array}{c}\text { NS } \\
0.01<P<0.025 \\
N S \\
N S \\
N S \\
P=0.025\end{array}$ \\
\hline \multicolumn{9}{|c|}{$\begin{array}{l}\text { Campania } \\
\text { (southern Italy) }\end{array}$} \\
\hline $\begin{array}{l}\text { January } \\
\text { February } \\
\text { March } \\
\text { April } \\
\text { May } \\
\text { June }\end{array}$ & $\begin{array}{l}1982-1986 \\
1982-1986 \\
1982-1986 \\
1977-1986 \\
1977-1986 \\
1977-1986\end{array}$ & $\begin{array}{l}0.93 \\
0.84 \\
0.84 \\
0.72 \\
0.86 \\
0.95\end{array}$ & $\begin{array}{l}20969 \\
18306 \\
22008 \\
21577 \\
22575 \\
22998\end{array}$ & $\begin{array}{l}21054 \\
19237 \\
22427 \\
21170 \\
23241 \\
21995\end{array}$ & $\begin{array}{r}411.9 \\
939.0 \\
1503.0 \\
1344.2 \\
1116.8 \\
636.0\end{array}$ & $\begin{array}{l}19743-22365 \\
16249-22225 \\
18255-26599 \\
18610-23730 \\
21114-25368 \\
20784-23206\end{array}$ & $\begin{array}{r}-0.40 \\
-4.84 \\
-1.87 \\
1.92 \\
-2.87 \\
4.56\end{array}$ & $\begin{array}{l}\text { NS } \\
\text { NS } \\
\text { NS } \\
\text { NS } \\
\text { NS } \\
\text { NS }\end{array}$ \\
\hline
\end{tabular}

Table 2. Induced abortion rates for 100 known pregnancies by month in three selected regions of Italy in 1986. ( $E=$ expected, $\mathrm{O}=$ observed, $95 \% \mathrm{Cl}=95 \%$ confidence interval)

\begin{tabular}{|c|c|c|c|c|c|c|}
\hline \multirow{2}{*}{ Region } & \multirow{2}{*}{$\begin{array}{l}\text { Induced } \\
\text { abortions } \\
\text { (N) }\end{array}$} & \multicolumn{3}{|c|}{ Induced abortion rates } & \multirow{2}{*}{ Z } & \multirow{2}{*}{$\begin{array}{l}\text { 2-tailed } \\
\text { P-value }\end{array}$} \\
\hline & & $E$ & 0 & $95 \% \mathrm{Cl}$ & & \\
\hline \multicolumn{7}{|c|}{ Lombardia (northern Italy) } \\
\hline $\begin{array}{l}\text { May } \\
\text { June } \\
\text { July } \\
\text { August }\end{array}$ & $\begin{array}{l}2811 \\
2662 \\
2736 \\
1770\end{array}$ & $\begin{array}{l}34.12 \\
31.15 \\
31.81 \\
28.52\end{array}$ & $\begin{array}{l}30.23 \\
31.64 \\
32.88 \\
26.54\end{array}$ & $\begin{array}{l}29.30-31.18 \\
30.65-32.65 \\
31.87-33.90 \\
25.49-27.62\end{array}$ & $\begin{array}{r}-7.92 \\
0.96 \\
2.09 \\
-3.59\end{array}$ & $\begin{array}{c}<0.0001 \\
N S \\
0.01<P<0.05 \\
<0.0005\end{array}$ \\
\hline \multicolumn{7}{|c|}{ Lazio (central Italy) } \\
\hline $\begin{array}{l}\text { May } \\
\text { June } \\
\text { July } \\
\text { August }\end{array}$ & $\begin{array}{l}2027 \\
1940 \\
1994 \\
1399\end{array}$ & $\begin{array}{l}35.95 \\
34.85 \\
36.30 \\
32.03\end{array}$ & $\begin{array}{l}31.91 \\
34.32 \\
33.84 \\
28.88\end{array}$ & $\begin{array}{l}31.07-33.40 \\
33.33-35.84 \\
32.46-34.89 \\
27.55-30.12\end{array}$ & $\begin{array}{l}-6.17 \\
-0.45 \\
-4.23 \\
-4.81\end{array}$ & $\begin{array}{l}<0.0001 \\
\text { NS } \\
<0.0001 \\
<0.0001\end{array}$ \\
\hline \multicolumn{7}{|c|}{ Campania (southern Italy) } \\
\hline $\begin{array}{l}\text { May } \\
\text { June } \\
\text { July } \\
\text { August }\end{array}$ & $\begin{array}{r}1328 \\
1279 \\
1215 \\
898\end{array}$ & $\begin{array}{l}16.23 \\
11.76 \\
17.97 \\
13.49\end{array}$ & $\begin{array}{l}16.17 \\
13.25 \\
16.00 \\
14.07\end{array}$ & $\begin{array}{l}15.38-16.99 \\
12.58-13.94 \\
15.18-16.84 \\
13.23-14.95\end{array}$ & $\begin{array}{r}-0.17 \\
4.52 \\
-4.56 \\
1.33\end{array}$ & $\begin{aligned} & \text { NS } \\
&< 0.0001 \\
&< 0.0001 \\
& \text { NS }\end{aligned}$ \\
\hline
\end{tabular}


may show up in extreme circumstances as a higher rate of induced abortion and a lower rate of birth (18). Studies in Sweden on the level of concern following Chernobyl showed that the level of concern mirrored the level of radioactivity reported by the media (4).

Several investigations on the outcomes of pregnancies exposed to the radiation following Chernobyl were carried out in the European countries reached by the radioactive cloud. In Greece the number of births in the first three months of 1987 was 22637 versus 25201 expected (for a decrease in the birth rate of $10.2 \%$ ) (3). Data on induced abortions were not available in Greece; nevertheless the authors attributed the reduction in births entirely to an increase in terminations of pregnancy. In Sweden the conception rate went down in June-August 1986 and a slight increase in the number of induced abortions was observed in the same cohort of conceptions (4). No increase in the number of spontaneous abortions, congenital malformations, or preterm births was detected. The author attributed his finding to the effect of public scare, which produced a decrease in the number of planned pregnancies and a termination of some of them. In Finland a slight decrease in the birth rate was observed $(-0.5 \%)$ in January-March 1987 (19). The incidence of congenital malformations was not increased even though a higher occurrence of premature births was detected among malformed children. The latter finding was considered to be unexplainable by the authors.

A decrease in the birth rate and a slight increase in the number of induced abortions were observed in Italy in the first months following the Chernobyl accident. The data on induced abortions must be interpreted with caution. The abortion rates in 1986 were in general lower than those observed in 1985: $-2.30 \%$ for the country as a whole $(-1.33 \%$ in Lombardia, $-4.66 \%$ in Lazio, +0.10\% in Campania) (Spinelli A, unpublished data, 1988). The 1986 data confirmed a tendency first observed when 1984 and 1985 data were compared. Therefore the expected rates, as calculated, could have involved an overestimation of the expected figures for 1986 and could therefore account for the statistically significant lower than expected rates reported for several months. Nevertheless the increase in the number of induced abortions observed in Lombardia in June and July is interesting even though not statistically significant. It was observed in the "at risk months" despite an overall tendency towards a de-

Table 3. Preterm births ( $<37$ weeks) in the Lazio region (central Italy) in October-December (1985-1986).

\begin{tabular}{|c|c|c|c|c|c|}
\hline \multirow{2}{*}{ Months } & \multicolumn{2}{|c|}{$\begin{array}{c}1985 \\
\text { Births }\end{array}$} & \multicolumn{2}{|c|}{$\begin{array}{c}1986 \\
\text { Births }\end{array}$} & \multirow{2}{*}{$\begin{array}{l}\text { Chi- } \\
\text { square } \\
\text { P-value }\end{array}$} \\
\hline & Preterm & Total & Preterm & Total & \\
\hline $\begin{array}{l}\text { October } \\
\text { November } \\
\text { December }\end{array}$ & $\begin{array}{l}302 \\
258 \\
274\end{array}$ & $\begin{array}{l}4200 \\
3490 \\
3496\end{array}$ & $\begin{array}{l}265 \\
254 \\
251\end{array}$ & $\begin{array}{l}3869 \\
3553 \\
3505\end{array}$ & $\begin{array}{l}\text { NS } \\
\text { NS } \\
\text { NS }\end{array}$ \\
\hline
\end{tabular}

crease in the number of induced abortions. The data from Campania are more difficult to interpret. The base-line rates have probably been underestimated, and a large use of illegal abortion in that region cannot be ruled out. In Lazio no increase in the abortion rate was detected. In general, Italian data do not support the hypothesis of a large increase in the number of induced abortions after the Chernobyl accident.

There are several possible explanations of the reduction of births observed in January-March 1987. First of all, a decrease in the number of "planned pregnancies" could have occurred. This hypothesis is supported by the increase in the number of births in April-June 1987, which could mean a postponement of planned pregnancies to "safer" times, mainly in the north and center of the country. Well-known differences between north-central Italy and the south in socioeconomic status, access to health services, and prevalence of contraception (20), in addition to the perceived radiation risk due to the higher level of radioactive contamination in the north and in the center of the country, could have played a role in determining the heterogeneity of the data on births in the three areas.

Another possibility is that radiation increased the number of spontaneous abortions, and this phenomenon could have been followed by an increase in the number of replacement pregnancies soon afterwards. This hypothesis cannot be excluded because data on subclinical, early spontaneous abortions and reliable figures on clinical spontaneous abortions were not available. However data from Sweden (where radiation exposure was higher than in Italy) do not show any increase in spontaneous abortions in the months following the accident (3).

$A$ decrease in the number of births in January-March 1987 could also have been due to an increase in the number of preterm births in the last months of 1986 among babies conceived around the time of the accident. Data on gestational age with respect to all Italjan births were not available. However it was possible to check figures on the gestational age for births in the Lazio region (central Italy) (Bertollini $R$, unpublished data, 1989). The data were collected for the Medical Birth Registry established for that area (21) (table 3). Preterm births ( $<37$ weeks of gestational age) were not increased in October-December 1986 as compared with the corresponding rate during the same months of 1985.

Finally the decrease in births could be simply the effect of natural variation in the monthly number of births. This possibility seems unlikely, at least for those differences which reached statistical significance.

In conclusion, Italian data show a decrease in the number of births and a slight increase in the number of induced abortions in the months following the Chernobyl accident. These data are consistent with those coming from other European countries $(3,4)$ and are most likely attributable to a decrease in the number of planned pregnancies and the termination of some 
of them, although other hypotheses cannot be totally ruled out. The Italian data suggest a high perceived radiation risk in the population more in association with the impact, quality, and timing of information spread by the media and public health authorities than with the actual level of radiation exposure. The change in the frequency of births and the number of induced abortions was limited to the first period of contamination, even though the radioactivity due to Chernobyl continued to persist in the environment and increased in body fluids for several months after the accident (22) as a consequence of the accumulation of the longer lived radioisotopes of caesium $\left(\mathrm{Cs}^{134}\right.$ and $\mathrm{Cs}^{137}$ ). However, considering the uncertainties related to exposure levels and the controversies about the long-term effects of low-dose radiation exposure in humans (13), the reaction of the population seems to have been the "best possible"' adjustment to a sudden unknown risk.

\section{Acknowledgments}

We thank the Regional Office for Abortion Surveillance of Lombardia and Campania for providing the data on abortions, Ms Francucci of the Italian Institute of Statistics for the data on births, Ms L Hoffman for retrieving the data on media coverage, and Dr P Papini for his statistical advice. We are indebted to Ms P Di Lena and to Ms D Gittarelli for their invaluable help with the data collection.

\section{References}

1. Risica S. The environmental risk in power production: experimental results, calculations and considerations after Chernobyl. Ann Ist Super Sanita 1987;23(2):177522.

2. Anonymous. Newsline: lessons of Chernobyl, part II. J Nucl Med 1987;28:933-42.

3. Trichopoulos D, Zavitsanos X, Koutis C, et al. The victims of Chernobyl in Greece: induced abortions after the accident. Br Med J 1987;295:1100.

4. Källén B. Pregnancy outcome in Sweden after Chernobyl - a study with central health registries. Stockholm: National Board of Health, 1988.

5. Bertazzi PA. Industrial disasters and epidemiology: a review of recent experiences. Scand J Work Environ Health 1989;15:85-100.

6. Istituto Centrale di Statistica (ISTAT). Bollettino mensile di statistica. Rome: ISTAT. (Giugno 1977-Settembre 1987.)

7. Snedecor GW, Cochran WG. Statistical methods. 7th ed. Ames, IA: Iowa State University Press, 1980: 166-9.

8. Tietze C. Induced abortions: a world review, 1981. New York, NY: Population Council, 1981. (A Population Council Fact Book.)

9. Spinelli A, Grandolfo ME, De Blasio R, et al. L'Interruzione volontaria di gravidanza in Italia. Roma: Istituto Superiore di Sanita', 1987. (Rapporti ISTISAN.)

10. Snedecor GW, Cochran WG. Statistical methods. 7th ed. Ames, IA: Iowa State University Press, 1980: 117-25.

11. Fleiss JL. Statistical methods for rates and proportions. 2nd ed. New York, NY: John Wiley \& Sons, 1981:14-5.

12. United Nations Scientific Committee on the Effects of Atomic Radiation (UNSCEAR). Sources, effects and risks of ionizing radiation: report of the 37th session with annexes. Vienna: UNSCEAR (in press).

13. Russel J, Southwood R, ed. Radiation and health: the biological effects of low level exposure to ionizing radiation. Chichester: John Wiley \& Sons, 1987.

14. Brent RL. Radiation teratogenesis. Teratology 1980; 21:281-98.

15. International Commission on Radiological Protection. Statement from the 1983 Washington meeting of the ICRP. Ann ICRP 1985;14:1-7.

16. Baker ML, Vandergrift GF, Dalrymple GW. Fetal exposure in diagnostic radiology. Health Phys 1979;37: 237-9.

17. Sever LE, Gilbert ES, Hessol NA, McIntyre JM. A case control study of congenital malformations and occupational exposure to low level ionizing radiation. Am J Epidemiol 1988;127(2):226-42.

18. Pershagen G. Health effects of Chernobyl. Br Med J 1988;297:1488-9.

19. Harjuletho T, Aro T, Rita $\mathrm{H}$, et al. The accident at Chernobyl and outcome of pregnancy in Finland. $\mathrm{Br}$ Med J 1989;298:995-7.

20. Anonymous. Few Italian women use modern contraceptives; abortion is widespread. Fam Plann Perspect 1987; 19(1):27-8.

21. Bertollini R, Di Lallo D, Perucci CA, et al. Description and validation of the natality and infant mortality information system in Lazio. Neonatologica 1988;2(1): $26-34$.

22. Di Lallo D, Bertollini R, Perucci CA, et al. Radioactivity in breast milk in Central Italy in the aftermath of Chernobyl. Acta Paediatr Scand 1987;76:530-1.

Received for publication: 27 July 1989 